\section{Alexandre Grangeiro'}

Maria Mercedes Escuder"

Karina Wolffenbüttel"II

Ligia Rivero Pupo"

Maria Ines Battistella Nemes'

Paulo Henrique Nico Monteiro"

\section{Technological profile assessment of voluntary HIV counseling and testing centers in Brazil}

Departamento de Medicina Preventiva. Faculdade de Medicina. Universidade de São Paulo. São Paulo, SP, Brasil

Instituto de Saúde. Secretaria de Estado da Saúde de São Paulo (SES-SP). São Paulo, SP, Brasil

III Centro de Referência e Treinamento em DST/AIDS. SES-SP. São Paulo, SP, Brasil

\footnotetext{
Correspondence:

Alexandre Grangeiro

Av. Dr. Arnaldo $455,2^{\circ}$ andar

Cerqueira César

01246-903 São Paulo, SP, Brasil

E-mail: ale.grangeiro@gmail.com
}

\begin{abstract}
OBJECTIVE: To characterize and analyze technological profiles of voluntary HIV counseling and testing centers in Brazil.

METHODS: A structured self-completion questionnaire with 78 questions was used. This questionnaire was answered by $320(83.6 \%)$ of the 383 Brazilian centers, in 2006. Responses that characterized the services' technological profile were analyzed using K-means clustering technique. Associations between the profiles described and the municipal contexts were analyzed using the chi-square and residue analysis for proportions, and ANOVA and Bonferroni for means.

RESULTS: Centers showed significant deficiencies to guarantee adequate services. A total of four technological profiles were identified. The "care" profile $(21.6 \%)$ predominated among the services instituted before 1993, in areas with high AIDS incidence and in large cities. The "prevention" profile (30.0\%), prevalent between 1994 and 1998, was the type that best complies with the Ministry of Health's norms, with better readiness and productivity indicators. The "care and prevention" profile (26.9\%), included in the AIDS services, predominated between 1999 and 2002, and developed the most comprehensive set of activities, including STD treatment. The "testing" profile $(21.6 \%)$ was the most precarious, found where the epidemic is most recent and with a lower number of people tested.
\end{abstract}

CONCLUSIONS: Counseling and testing centers constitute a set of heterogeneous services. In addition, service implementation guidelines have not been completely incorporated in Brazil, thus having and influence on low resolution and productivity indicators and also the inadequate development of prevention activities.

DESCRIPTORS: Acquired Immunodeficiency Syndrome, prevention \& control. AIDS Serodiagnosis. Health Service Access. Health Service Assessment. Health Care Quality, Access and Assessment.

\section{INTRODUCTION}

In the 1980's, when the first tests for HIV diagnosis appeared, a service network named Centros de Testagem e Aconselhamento - $\mathrm{CTA}^{\mathrm{a}}$ (Voluntary Counseling and Testing Centers - VCT) began to be organized in Brazil. This was the first alternative to promote, anonymously and voluntarily, access to information

a Ministério da Saúde. Programa Nacional de DST e AIDS. Normas de organização e funcionamento dos Centros de Orientação e Apoio Sorológico. Brasília; 1993. 
on diseases, prevention materials and AIDS services by the population. ${ }^{21}$ This service network also aimed to increase blood transfusion safety, helping individuals who sought blood banks to have the anti-HIV test performed. ${ }^{1,20}$

The first norms of the Ministry of Health ${ }^{\mathrm{a}}$ recommended services to be established with multidisciplinary teams, where there is a great flow of population, and independently from existing health services. To achieve this, in the 1990's, the Ministry of Health funded projects to establish a service network in cities with significant HIV prevalence, a process which was subsequently decentralized. ${ }^{22, \mathrm{~b}}$

The CTA's role changed in the late 1990's, ${ }^{\mathrm{b}}$ as a result of changes in the epidemic's tendency ${ }^{2,6,15}$ and the incorporation of technological innovations for HIV diagnosis and disease treatment. ${ }^{7,11,19}$ Among these changes are the need to promote early HIV infection diagnosis and increase the number of clients served, including women, heterosexuals and low-income individuals; and to incorporate hepatitis diagnosis and HIV rapid tests, especially in areas with less developed laboratory infrastructure. $^{\mathrm{c}}$

Changes in the epidemic and policies adopted, such as the AIDS program decentralization, the adoption of strategies to reduce vertical transmission and the campaigns to promote anti-HIV testing contributed to reorganize the CTA network. In this way, new directives caused the requirement of client anonymity to be optional; expanded prevention activities, developing actions for vulnerable populations and in the community; incorporated vertical transmission prevention activities, performing diagnosis in pregnant women; and increased interaction with outpatient services to guarantee access and infected individuals' adherence to services and antiretroviral therapy. ${ }^{\mathrm{b}}$ Concomitantly, the Ministry of Health began to recommend the availability of diagnosis in primary care, especially in prenatal care, tuberculosis clinics and population served by family health teams.

These different organizational situations have contributed for the CTA organization and functioning to occur with specific characteristics and in some unknown way.
Moreover, there are no studies that analyze service characteristics on a national basis, as well as their contribution to control the epidemic in Brazil. Despite these specific characteristics studies have shown that diagnosis promotion policies, including the CTA proposal, yield poor results. Among these results, it is estimated that $70 \%$ of the adult Brazilian population has never had an anti-HIV test performed, ${ }^{\mathrm{d}}$ a proportion reaching $34.2 \%$ of drug users ${ }^{4} 72.7 \%$ of men who have sex with other men and $63.5 \%$ of sex workers not included in prevention activities. ${ }^{\mathrm{d}}$ In addition, similarly to developed countries, ${ }^{8}$ over $40 \%$ of the infected people begin clinical follow-up late, resulting in severe immunological impairment, and $48 \%$ of pregnant women infected are not identified, missing the opportunity to prevent vertical transmission. ${ }^{18}$

This study aimed to characterize and analyze technological profiles of the national network of voluntary counseling and testing centers, associating them with the network establishment's history and with the municipality contexts.

\section{METHODS}

A total of 383 services, self-denominated CTAs or thus denominated by national and state STD and AIDS programs, were included in this study, regardless of other organizational characteristics and inclusion in the health system. CTAs were identified from the National STD and AIDS Program registration database and from information of the health state departments in 2006.

The technological profile analyzed considered the service health work process (structure and activities performed) that characterize each CTA or groups of CTA. ${ }^{9,14}$ Information was obtained from a structured self-completion questionnaire, designed and used in the research study "Situational Diagnosis of Counseling Centers in Brazil". ${ }^{f}$

The self-completion questionnaire with 78 questions was mailed to service managers between August 2006 and January 2007. Inconsistent responses were checked by telephone.

The variables analyzed refer to: structure - the existence

\footnotetext{
a Ministério da Saúde. Programa Nacional de DST e AIDS. Normas de organização e funcionamento dos Centros de Orientação e Apoio Sorológico. Brasília; 1993.

b Ministério da Saúde. Programa Nacional de DST e AIDS. Diretrizes dos Centros de Testagem e Aconselhamento (CTA) - Manual. Brasília; 1999. c Ministério da Saúde. Programa Nacional de DST e AIDS. Teste rápido - Por que não? Estudos que contribuíram para a política de ampliação da testagem para o HIV no Brasil. Brasília; 2007.

${ }^{d}$ Ministério da Saúde. Programa Nacional de DST e AIDS. Pesquisa de conhecimento, atitudes e práticas na população brasileira de 15 a 54 anos, 2004. Brasília; 2005.

e França-Junior I, Lopes F, Paiva V, Venturi G. Acesso ao Teste Anti-HIV no Brasil 2003: A Pesquisa MS/lbope. Brasília: Ministério da Saúde; 2003 [cited 2009 Feb 24]. Available from: http://www.aids.gov.br/data/documents/storedDocuments/\%7BB8EF5DAF-23AE-4891-AD361903553A3174\%7D/\%7B7B791F50-5AC7-4F86-ABE7-1C7A578EBFB3\%7D/artigo_teste.pdf

${ }^{f}$ Grangeiro A, Martison B, Meireles da Silva CG, Barreira D, Ferraz D, Rocha F, et al. Diagnóstico Situacional dos Centros de Testagem e Aconselhamento no Brasil - Relatório de pesquisa. São Paulo; 2007. [cited 2009 Mar 16]. Available from: http://www.aids.gov.br/data/ documents/storedDocuments/\%7BB8EF5DAF-23AE-4891-AD36-1903553A3174\%7D/\%7B1D6F289E-CEDA-42B0-94F5-89683D6772DA\%7D/ relatorio_situacional_cta.pdf
} 
of a minimum physical area (individual and group counseling, waiting, and blood collection rooms), the presence of doctors in the team $(\%$ in relation to the total number of professionals), and the existence of prevention materials (male and female condoms and gel lubricant); clients served - origin of demand and social segment they belong to; activities performed - serological tests available, prevention actions in and out of the service sphere, STD treatment and the availability of specialized service referrals; and access - possibility of an anonymous service, mandatory pre- and post-test counseling and visit time.

Analysis was performed in two dimensions: description of technological profiles and analysis of the context where CTAs are included. K-means clustering analysis ${ }^{16}$ was used to describe the profiles, with nominal variables turned into dichotomic variables, attributing values to the absence (0) and presence (1) of each attribute studied. The permanence of variables in the analytical model was defined using the ANOVA variance analysis test, adopting a 0.05 level of significance.

Characterization of technological profiles was based on the percentages of occurrence of variables included in the analytical model.

The second dimension of the study - context analysis - was performed by means of a study of association between different technological profiles and the period of service implementation, its geographical distribution and health system and AIDS epidemiological characteristics, with special attention to public investments and reproductive health policy. The following indicators were considered for this analysis: year and area of service implementation, population and municipal HDI, number of AIDS cases, CTA inclusion in the health system, pre-natal coverage and public health expenses. Indicators were based on the Unified Health System Department of Computer Sciences (Datasus), the Instituto Brasileiro de Geografia e Estatística (IBGE - Brazilian Institute of Geography and Statistics) and the (Sinan Information System on Disease Notification).

To analyze the context, cities were considered as a unit of study, and each city's technological profile was characterized, i.e., the profile present in more than $50 \%$ of the CTAs established in this location. The cities of Aracaju (state of Sergipe), Contagem (state of Minas Gerais), Cuiabá (state of Mato Grosso), Manaus (state of Amazonas), Ribeirão Preto (state of São Paulo), Rio de Janeiro (state of Rio de Janeiro), São Paulo (state of São Paulo) e Sinop (state of Mato Grosso) were excluded from this analysis as they did not have a defined technological profile.

In addition, technological profiles were analyzed according to their capacity to make HIV diagnosis available, considering the information included in the self- completion questionnaire: population served (inclusion of vulnerable populations and positive HIV rate among clients), testing productivity (number of tests performed daily by a university professional/technician) and readiness (user's length of stay in the service and delivery of test result and return rate).

Chi-square test and residue analysis on a contingency table (Zres), with a 0.05 significance level, were used to analyze associations. Considering the $95 \%$ confidence level, every Zres $>|1,96|$ was regarded as either excess or lack of occurrence. ${ }^{16}$ ANOVA variance analysis was used to compare means of indicators observed in each technological profile, with the application of Bonferroni test for multiple comparisons.

This study was approved by the Instituto de Saúde (Institute of Health) Research Ethics Committee of the State of São Paulo Department of Health (Protocol 06/2006).

\section{RESULTS}

As regards the technological profile, information about 320 CTAs that answered the survey was analyzed $(83.6 \%)$ (Table 1$)$ with response rates varying between $72.3 \%$ in Brazil's Center-West region and $90.6 \%$ in the Southeast region. The CTAs analyzed were concentrated in the Southeast (39.4\%) and Northeast regions $(17.5 \%)$ (Table 2$)$, of which the majority $(81.9 \%)$ were classified as small- and average-sized, with a production of 1.7 anti-HIV tests/day per university professional/ technician. Rates above $1 \%$ HIV positivity were reported by $63.1 \%$ of the services (Table 3 ). Readiness indicators for testing were relatively low: $19.1 \%$ of the services showed user's length of stay in the service below one hour, with delivery of test results in up to 15 days and a return rate above $60 \%$ (Table 3 ).

In the analysis of the three populations mainly served in each service, the general population $(91.9 \%)$, pregnant women $(49.1 \%)$ and vulnerable populations (30.6\%) were more prevalent. Among the activities reported, preventive activities in the community for the general and vulnerable populations $(59.4 \%)$, the availability of a minimum syphilis, hepatitis and HIV serology set $(65.6 \%)$ and the STD service $(56.3 \%)$ predominated (Table 1).

Physical structure was found to be precarious in $44.4 \%$ of the services, as these did not have a minimum space for the client's reception, performance of counseling activities and biological material collection. Of all the services, $18.8 \%$ had all STD prevention materials, such as male and female condos and gel lubricant (Table 1).

Work process analysis characterizing the CTA network, denominated technological profile, enabled the identification of four service groups, different from each 
Table 1. Technological profile of counseling and testing centers and percentage distribution of structural characteristics, service clientele, activities developed and access criteria. Brazil, 2006.

\begin{tabular}{|c|c|c|c|c|c|}
\hline \multirow[b]{2}{*}{ Characteristic } & \multicolumn{4}{|c|}{ Profile (\%) } & \multirow[b]{2}{*}{$\begin{array}{c}\text { Total } \\
(\mathrm{N}=320)\end{array}$} \\
\hline & $\begin{array}{l}\text { Care } \\
(n=69)\end{array}$ & $\begin{array}{l}\text { Prevention } \\
\quad(n=96)\end{array}$ & $\begin{array}{c}\text { Care and } \\
\text { prevention } \\
(\mathrm{n}=86)\end{array}$ & $\begin{array}{l}\text { Testing } \\
(\mathrm{n}=69) \\
\end{array}$ & \\
\hline \multicolumn{6}{|l|}{ Structure } \\
\hline $\begin{array}{l}\text { Presence of individual and group counseling, waiting and } \\
\text { collection rooms }\end{array}$ & 55.1 & 62.5 & 61.6 & 39.1 & 55.6 \\
\hline Blood sample collection in the service itself & 65.2 & 88.5 & 50.0 & 52.2 & 65.3 \\
\hline Availability of male and female condoms and gel lubricant & 11.6 & 35.4 & 18.6 & 2.9 & 18.8 \\
\hline Doctors in the technical team & 17.9 & 9.1 & 24.0 & 15.7 & 16.5 \\
\hline \multicolumn{6}{|l|}{ Service clientele } \\
\hline Vulnerable populations & 47.8 & 50.0 & 17.4 & 2.9 & 30.6 \\
\hline Secondary service referral & 39.1 & 3.1 & 51.2 & 13.0 & 25.9 \\
\hline Pregnant women & 4.3 & 45.8 & 45.3 & 98.6 & 49.1 \\
\hline \multicolumn{6}{|l|}{ Activities performed } \\
\hline \multicolumn{6}{|l|}{ Prevention inside the unit } \\
\hline Vulnerable population & 33.3 & 56.3 & 64.0 & 17.4 & 45.0 \\
\hline $\begin{array}{l}\text { Therapy adherence groups and/or counseling for HIV- } \\
\text { discordant couples }\end{array}$ & 20.3 & 27.1 & 44.2 & 4.3 & 25.3 \\
\hline \multicolumn{6}{|l|}{ Prevention outside the unit } \\
\hline Not performed & 15.9 & - & - & 21.7 & 8.1 \\
\hline For the general population & 79.7 & - & 1.2 & 50.7 & 28.4 \\
\hline For the general and vulnerable population & - & 95.8 & 97.7 & 20.3 & 59.4 \\
\hline Harm reduction & 02.9 & 19.8 & 17.4 & - & 11.3 \\
\hline Mobile CTA & 13.0 & 65.6 & 37.2 & 20.3 & 36.9 \\
\hline \multicolumn{6}{|l|}{ Diagnosis and care } \\
\hline HIV, syphilis, and hepatitis B and C serology & 79.7 & 65.6 & 81.4 & 31.9 & 65.6 \\
\hline STD treatment & 60.9 & 27.1 & 91.9 & 47.8 & 56.3 \\
\hline Formal care referral & 63.8 & 61.5 & 89.5 & 58.0 & 68.7 \\
\hline \multicolumn{6}{|l|}{ Access } \\
\hline Night service & 8.7 & 24.0 & 14.0 & 1.4 & 13.1 \\
\hline Free identification (password, nickname or name) & 60.9 & 84.4 & 40.7 & 33.3 & 56.6 \\
\hline Pre- or post-test counseling not mandatory & 15.9 & 31.3 & 30.2 & 7.2 & 22.5 \\
\hline
\end{tabular}

CTA: Counseling and testing center

STD: Sexually transmitted disease

other and with distinct vocations and natures, which were used to name each group, as detailed below (Tables 1 and 2).

In the "testing" profile, 69 services were identified, corresponding to $21.6 \%$ of the universe studied. Services were mostly directed towards offering HIV diagnosis, with a priority service for pregnant women as a vertical transmission prevention strategy. This set of services had the lowest positive anti-HIV test rates, of which $50 \%$ showed rates below $1 \%$. In addition, they were the ones that least performed the activities recommended by the Ministry of Health, such as the availability of syphilis and hepatitis $\mathrm{B}$ and $\mathrm{C}$ diagnosis and the development of prevention and care activities. CTAs that showed precarious physical structure, deficiency in the establishment of care referrals, low availability of prevention materials and restrictive criteria for user access, with mandatory identification and pre-test counseling comprised this group.

The "care" profile was also comprised by 69 CTAs (21.6\% of services) and was characterized as the group in which individual care prevailed, mainly offering STD treatment and HIV, syphilis and hepatitis serological tests. However, services of this profile showed the worst readiness indicators, performing the lowest number of anti-HIV tests per university professional/ technician (1.4 tests/day) and the smallest proportion of CTAs with delivery of test results in up to 15 days 
Table 2. Standardized residual (Zres) of technological profiles per region, location, health network inclusion and implementation period. Brazil, 2006.

\begin{tabular}{|c|c|c|c|c|c|c|}
\hline \multirow[b]{2}{*}{ Characteristic } & \multicolumn{6}{|c|}{ Profile } \\
\hline & $\begin{array}{l}\text { Total } \\
\text { N (\%) }\end{array}$ & Care & Prevention & $\begin{array}{l}\text { Prevention } \\
\text { and care }\end{array}$ & Testing & $\mathrm{p}$ \\
\hline Region & & & & & & $<0.05$ \\
\hline Center-West & $47(14.7)$ & -0.8 & -1.4 & 1.2 & 1.1 & \\
\hline Northern & $40(12.5)$ & -1.5 & -2.2 & -1.4 & 5.5 & \\
\hline Northeast & $56(17.5)$ & -3.2 & 3.9 & 0.0 & -1.1 & \\
\hline Southern & $51(15.9)$ & 0.7 & -0.1 & -1.3 & 0.7 & \\
\hline Southeast & $126(39.4)$ & 3.6 & -0.4 & 1.1 & -4.2 & \\
\hline City size (per 1,000 inhabitants) & & & & & & $<0.05$ \\
\hline Up to 50 & $36(11.3)$ & -1.6 & -2.6 & 0.1 & 4.4 & \\
\hline $50-100$ & $68(21.3)$ & -3.5 & 0.5 & 3.0 & -0.2 & \\
\hline $100-200$ & $64(20.0)$ & -1.0 & -0.1 & 0.3 & 0.7 & \\
\hline $200-500$ & $69(21.6)$ & 1.0 & 2.2 & -2.6 & -0.6 & \\
\hline More than 500 & $83(25.9)$ & 4.4 & -0.5 & -0.7 & -3.1 & \\
\hline Inclusion in the health network & & & & & & $<0.05$ \\
\hline Not included in health care services & $35(10.9)$ & -1.1 & 3.7 & -3.0 & 0.2 & \\
\hline AIDS SAE and specialized services & $151(47.2)$ & 2.8 & -2.8 & 2.1 & -2.1 & \\
\hline Basic health care unit & $65(20.3)$ & -0.3 & -2.0 & -1.1 & 3.7 & \\
\hline In programs & $23(7.2)$ & -2.1 & 3.4 & -1.1 & -0.5 & \\
\hline In programs and secondary health care units & $46(14.1)$ & -1.1 & 0.4 & 1.7 & -1.1 & \\
\hline Implementation period & & & & & & $<0.05$ \\
\hline Until 1993 & $23(7.2)$ & 2.1 & -0.4 & -1.6 & 0.0 & \\
\hline From 1994 to 1998 & $110(34.4)$ & 0.4 & 4.4 & -1.7 & -3.4 & \\
\hline From 1999 to 2002 & $89(27.8)$ & -1.3 & -1.8 & 2.8 & 0.2 & \\
\hline From 2003 onwards & $98(30.6)$ & -0.3 & -2.5 & -0.1 & 3.2 & \\
\hline
\end{tabular}

SAE: Specialized health care service

and to more than $60 \%$ of clients. This was the second group with fewer prevention actions inside and outside the unit and, when such actions were performed, they were directed towards the general population. Among the clientele served, there were a great number of vulnerable populations and individuals sent by the secondary care network. This technological profile, resulting from the clientele make-up, was comprised by services with the highest positive anti-HIV test rates: $24.6 \%$ were above $5 \%$.

The "care and prevention" profile was present in $26.8 \%$ (86) of services, and it was characterized by the development of the most comprehensive set of activities, performing preventive and care actions, both in and out of its sphere. This profile showed the highest availability for STD treatment and HIV, syphilis and hepatitis serological tests, with the best tools to refer infected people. In addition, it was the one that most performed prevention activities for vulnerable populations cared for in the unit. There were a proportionately higher number of doctors, compared to the other groups, and the clientele was comprised of referred patients and pregnant women.

The "prevention" profile was responsible for the highest number of centers, 96 (30.0\%). The object of work was characterized by offering prevention actions, inside and outside the unit, such as the existence of mobile CTAs, availability of prevention materials and execution of harm-reducing actions. This profile was the one that most adopted flexible criteria for client access, maintaining a night service and not requiring user identification and pre-test counseling. These services were those that most cared for vulnerable populations, showing the greatest diversity of social groups among the clientele served, including drug users, homosexuals, transvestites, and sex workers. In addition, they showed the best readiness and productivity indicators. The daily mean of tests per university professional/technician was 2.3 and it included the greatest proportion of services with delivery of test results in less than 15 days, with a user return rate above $60 \%$. Comparatively to other profiles, this group had the best physical structure and the lowest proportion of doctors in the team of professionals. 
Table 3. Proportion and standardized residual (Zres) of counseling and testing centers per readiness and productivity indicators. Brazil, 2006.

\begin{tabular}{|c|c|c|c|c|c|c|}
\hline \multirow[b]{2}{*}{ Indicator } & \multicolumn{6}{|c|}{ Profile $\%$ and (Zres) } \\
\hline & $\begin{array}{c}\text { Total } \\
\%\end{array}$ & Care & Prevention & $\begin{array}{l}\text { Prevention } \\
\text { and care }\end{array}$ & Testing & $\mathrm{p}$ \\
\hline \multicolumn{7}{|l|}{ Proportion of services that care for } \\
\hline $\begin{array}{l}\text { Sex professionals, homosexuals, transvestites and } \\
\text { transsexuals }\end{array}$ & 48.4 & $\begin{array}{l}12.8 \\
(1.8)\end{array}$ & $18.8(3.3)$ & $10.9(-1.7)$ & $6.3(-3.7)$ & $<0.00$ \\
\hline Drug users (injecting and non-injecting) & 27.5 & $7.8(1.8)$ & $11.6(2.9)$ & $5.0(-2.2)$ & $3.1(-2.7)$ & $<0.00$ \\
\hline Secondary health service referrals & 53.1 & $\begin{array}{l}12.2 \\
(0.6)\end{array}$ & $10.0(-4.6)$ & $19.1(3.9)$ & $11.9(0.4)$ & $<0.00$ \\
\hline Health professionals & 6.9 & $3.1(2.8)$ & $1.6(-0.8)$ & $0.9(-1.5)$ & $1.3(-0.4)$ & $<0.04$ \\
\hline Pregnant women & 52.8 & $3.1(-7.2)$ & $15.3(-0.4)$ & $13.1(-0.9)$ & $21.3(8.6)$ & $<0.00$ \\
\hline \multicolumn{7}{|l|}{ HIV prevalence } \\
\hline Services with less than $1 \%(\%)$ & 36.9 & $4.9(-2.5)$ & $12.3(-0.1)$ & $9.7(0.4)$ & $10.1(2.2)$ & $<0.00$ \\
\hline Services with more than $5 \%(\%)$ & 12.7 & $5.2(3.0)$ & $3.4(-0.9)$ & $3.0(-0.2)$ & $1.1(-1.8)$ & $<0.05$ \\
\hline \multicolumn{7}{|l|}{ Readiness } \\
\hline \multirow[t]{2}{*}{$\begin{array}{l}\text { Services with user length of stay below one hour, } \\
\text { delivery of test result in less than } 15 \text { days and } \\
\text { return rate above } 60 \%(\%)\end{array}$} & 19.1 & $2.2(-2.1)$ & $7.8(2.1)$ & $6.3(1.2)$ & $2.8(-1.4)$ & $<0.03$ \\
\hline & Mean & Mean & Mean & Mean & Mean & $\mathrm{p}$ \\
\hline \multicolumn{7}{|l|}{ Productivity $^{\mathbf{a}}$} \\
\hline $\begin{array}{l}\text { Mean number of tests/day per university } \\
\text { professional and technician }\end{array}$ & 1.7 & $1.3^{\mathbf{b}}$ & $2.3^{\mathbf{b}}$ & $1.4^{\mathrm{b}}$ & 1.9 & $<0.00$ \\
\hline
\end{tabular}

a Mean productivity tested with ANOVA, multiple differences with Bonferroni test

b Productivity of "prevention" profile was found to be different from the "care" and "prevention and care" profiles

In terms of context analysis, there was an important association between the technological profiles and the geographical, epidemiological, and health network (of the cities where it is included) characteristics, which may have contributed to the diversification in the way services were organized (Tables 2 and 4 ).
The first stage of CTA expansion, which occurred before 1993, was associated with the "care" technological profile and the CTAs located in the Southeast region, in cities with more than 500,000 inhabitants. This profile showed the best mean municipal human development indices (2000), the highest AIDS incidence rates, the

Table 4. Epidemiological, demographic, economic and health indicators, according to cities characterized by predominant technological profile. Brazil, 2006.

\begin{tabular}{|c|c|c|c|c|c|}
\hline \multirow[b]{2}{*}{ Indicator } & \multicolumn{5}{|c|}{ Technological profile } \\
\hline & Care & Prevention & $\begin{array}{l}\text { Prevention and } \\
\text { care }\end{array}$ & Testing & $\mathrm{p}$ \\
\hline \multicolumn{6}{|l|}{ Epidemiological } \\
\hline Number of AIDS cases between 2000 and 2005 & 34,972 & 29,809 & 14,123 & 6,967 & - \\
\hline Mean AIDS incidence per 100,000 inhabitants $^{\mathbf{a}}$ & 41.6 & 30.4 & 25.1 & 25.7 & $<0.05$ \\
\hline \multicolumn{6}{|l|}{ Demographic and economic } \\
\hline Average population & 336,857 & 234,190 & 135,446 & 116,729 & - \\
\hline HDI-C $(2000)^{\mathbf{a}}$ & 0.80 & 0.76 & 0.77 & 0.75 & $<0.05$ \\
\hline \multicolumn{6}{|l|}{ Health } \\
\hline Average per capita municipal health expenses (in $\mathrm{R} \$)^{\mathbf{a}}$ & 151.9 & 99.9 & 105.6 & 87.9 & $<0.05$ \\
\hline $\begin{array}{l}\text { Mean number of pregnant women with fewer than } \\
\text { four pre-natal visits }{ }^{\mathbf{b}_{(\%)}}\end{array}$ & 7.93 & 10.17 & 9.79 & 14.9 & $<0.05$ \\
\hline
\end{tabular}

HDI-C: Human Development Index of the city

a Significant difference between "care" profile and the other three profiles.

b Significant difference between "care" profile and basic profile. 
greatest number of doctors and medical visits per thousand inhabitants and the highest municipal health expenses (Tables 2 and 4).

The second stage of CTA expansion, between 1994 and 1998, was associated with "prevention" technological profile CTAs, which predominate in cities with 200,000 to 500,000 inhabitants, in the Northeast region. This was the second group in number of AIDS cases and in population, and it was the most prevalent profile among the CTAs not included in health units or which were associated with AIDS programs. The period of establishment of these CTAs coincided with the stage when the Ministry of Health funded service effectiveness projects.

The CTAs' third stage of expansion occurred between 1998 and 2002 and was related to the "care and prevention" group, better distributed throughout the country's administrative regions, and predominating in averagesized cities, with a number of inhabitants ranging between 50,000 and 100,000. The inclusion of these CTAs occurred mainly in specialized AIDS services, and the period of occurrence was characterized by the epidemic's spread to the countryside, the use of highpotency antiretroviral therapy, and the increase in the number of AIDS outpatient clinics.

"Testing" CTAs predominated among those established after 2003, in the Northern region, in small-sized cities with up to 50,000 inhabitants. These cities included the lowest number of people and AIDS cases and, when compared to cities with "care" CTA, showed the worst reproductive health indicators $-14.9 \%$ of pregnant women made less than four pre-natal visits (Table 4). Even though services with this profile were included on several health care levels, those established in primary care units predominated.

\section{DISCUSSION}

Findings suggest that, after two decades, the CTA network shows significant limitations to guarantee diagnosis service quality and prevention action development. This network's period of establishment, the epidemiological profile and regional and health network characteristics contributed to determine different CTA organization and functioning ways in Brazil, characterizing the existence of distinct technological profiles. The principles their establishment was founded upon have not been completely incorporated into the CTA work process, and the "prevention" profile was the one that best organized its activities, in accordance with equity and comprehensiveness directives. Furthermore, this profile adopts health practices centered on the community and individual needs - directives expressed as Ministry of Health norms for service organization. The "testing" profile was the model that least incorporated such principles.

Among the CTA limitations identified, four of them substantially restrict the capacity these services have to fulfill their role: precarious infrastructure, represented by a large number of services without minimum space to perform diagnosis, counseling and prevention activities; insufficient prevention actions due to a lack of materials and the reduced number of activities for vulnerable populations and in communities; low readiness, considering the long test result waiting time, the low number of tests performed and the reduced variety of tests available; and restrictive service access criteria, with a predominant day service and mandatory identification and pre-test counseling.

CTA precariousness has already been reported by other studies, which, in addition to what was previously described here, emphasize the fact that prevention actions are restricted to counseling; the small interaction with the health network, contributing to the fragility of mechanisms of care service referrals and integration with policies to fight the disease; and service inaction. ${ }^{12, \mathrm{a}, \mathrm{b}}$

Even though limitations can be observed in all technological profiles, the "testing" and "care" services show the major deficiencies, which may mean additional difficulties to fight the epidemic. CTAs with a "testing" profile, the most precarious ones, are established in areas where epidemics are more recent, characterized by high incidence growth rates. ${ }^{3}$ In addition, these areas showed the lowest proportion of population tested ${ }^{\mathrm{c}}$ and high late diagnosis prevalence, facts that require higher service response capacity to, among other things, minimize the greater health structure deficiency shown by this study's analysis.

CTAs with the "care" profile, in their turn, are established in areas with the highest AIDS incidence rates and a substantial proportion of cases in marginalized social classes. ${ }^{3}$ Even though these areas have better health structure, the fact that specialized services have been better assessed in their capacity to include vulnerable populations and to offer high-quality tests and counseling should be considered. ${ }^{17}$ This fact may contribute to promote equity among these regions.

Another aspect is the analysis of incorporation of directives upon which CTA establishment in Brazil

\footnotetext{
a Silva SMB. Centro de Testagem e Aconselhamento (CTA): caminhos e trilhas em construção. [dissertação de mestrado]. Rio de Janeiro: Universidade Federal do Rio de Janeiro; 2004

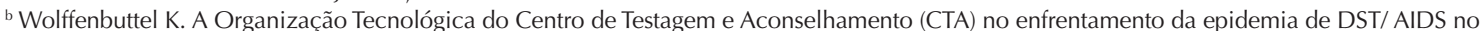
Estado de São Paulo. [dissertação de mestrado]. São Paulo: Faculdade de Ciências Médicas da Santa Casa; 2006.

c Ministério da Saúde. Programa Nacional de DST e AIDS. Pesquisa de conhecimento, atitudes e práticas na população brasileira de 15 a 54 anos, 2004. Brasília; 2005.
} 
was founded. In the late 1980's, in a context of great stigma associated with the disease and restructuring of the Brazilian health system, CTAs proposed the organization of an innovative service model ${ }^{12}$ which sought to overcome the common barriers of health network access and of service models founded upon doctor-individual care.

Analysis of the set of work processes predominating in the CTAs indicated, however, that the directives which presupposed a new service model organization had not been fully incorporated, a fact indicated by insufficient activities to promote health equity, comprehensiveness and practices centered on the community and individual needs. This aspect may contribute to the low readiness in diagnosis availability, service inaction, and reduced inclusion of vulnerable groups and those with high HIV prevalence.

Corroborating this hypothesis, the "prevention" and "prevention and care" technological profiles, which, comparatively, incorporated the recommended CTA organization principles more fully, are those that had the best performance, considering the indicators analyzed. This hypothesis had already been discussed by other studies, showing that service organization based on the needs and context of individuals contributes to increase action effectiveness ${ }^{10,13,17}$ and minimizes stigma associated with the disease. Moreover, the exclusion of common service access barriers, such as mandatory user identification, has been reported as an important requirement to promote diagnosis and the search for services. ${ }^{5,10}$

The present study did not aim to create a hierarchy among the different work processes that characterize CTAs, but sought to describe aspects that influenced the capacity of services to offer diagnosis and prevention actions. The technological profiles identified pointed out that each group has its own vocation and nature. These specificities were constituted from the contexts in which services are included and from the changes that occurred in the epidemic profile and disease-fighting policies, an aspect that should be analyzed in-depth by future studies.

In conclusion, by considering the characteristics of technological profiles when designing health policies, improving the attributes that characterize each group, the incorporation of national norms in the service context may be facilitated, causing epidemic-fighting strategies to be adequate for the local reality. To achieve this, it is necessary to incorporate the principles that guided CTA establishment into the work process of services, as well as to provide solutions to infrastructure problems and the lack of materials identified by this study. 


\section{REFERENCES}

1. Basso CR. O programa nacional de DST/AIDS no SUS. In: Barjas-Negri AL, D'Avila V, editores. O Sistema Único de Saúde em dez anos de desafio. São Paulo: Sobravine/Cealag; 2002. p. 135-62.

2. Bastos FI, Szwarcwald CL. AIDS e pauperização: principais conceitos e evidências empíricas. Cad Saude Publica. 2000;16(Supl 1):65-76. DOI: 10.1590/ S0102-311X2000000700006

3. Dourado I, Veras MASM, Barreira D, Brito, AM. Tendências da epidemia de Aids no Brasil após a terapia anti-retroviral. Rev Saude Publica. 2006;40(Supl):9-17. DOI: 10.1590/S003489102006000800003

4. Ferreira AD, Caiaffa WT, Bastos FI, Mingoti SA. Usuários de drogas injetáveis que (des)conhecem seu status sorológico para a infecção pelo HIV: achados do Projeto AJUDE-Brasil II. Cad Saude Publica. 2006;22(4):815-26. DOI: 10.1590/S0102$311 \times 2006000400020$

5. Ferreira MPS, Silva CMFP, Gomes MCF, Silva SMB. Testagem sorológica para o HIV e a importância dos Centros de Testagem e Aconselhamento (CTA) Resultado de uma pesquisa no município do Rio de Janeiro. Cienc Saude Coletiva. 2001;6(2):481-90. DOI: 10.1590/S1413-81232001000200017

6. Fonseca MG, Szwarcwald CL, Bastos FI. Análise sociodemográfica da epidemia de AIDS no Brasil, 1989-1997. Rev Saude Publica. 2002;36(6):678-85. DOI: 10.1590/S0034-89102002000700004

7. Galvão J. Brazil and access to HIV/AIDS drugs: a question of human rights and public heath. Am J Public Health. 2005;95(7):1110-16.

8. Girardi E, Sabin CA, Monforte AA. Late diagnosis of infection: epidemiological features, consequences and strategies to encourage earlier testing. J Acquir Immune Defic Syndr. 2007;46(Supl 1):3-8.

9. Gonçalves RBM. Tecnologia e organização social das práticas de saúde: características tecnológicas do processo de trabalho na Rede Estadual de Centros de Saúde de São Paulo. São Paulo: Hucitec; 1994.

10. Irwin KL, Valdisseri RO, Holberg SD. The acceptability of voluntary HIV antibody testing in the united states: a decade of lessons learned. AIDS. 1996;10(14):1707-17.

11. Levi GC, Vitoria MAA. Fighting Against AIDS: The Brazilian Experience. AIDS. 2002; 16(18):2373-83.
12. Minayo MCS, Souza ER, Assis SG, Cruz Neto O, Deslandes SF, Silva CMFP. Avaliação dos Centros de Orientação e Apoio Sorológico (CTA) COAS) da Região Nordeste do Brasil. Cad Saude Publica. 1999;15(2):355-67. DOI: 10.1590/S0102311X1999000200020

13. Myers T, Worthington C, Haubrich DJ, Ryder K, Calzavara L. HIV testing and counseling: test provider's experiences of best practices. AIDS Educ Prev. 2003;15(4):309-19.

14. Nemes MIB. Prática programática em saúde. In: Schraiber LB, Nemes MIB, Mendes-Gonçalves RB, editores. Saúde do adulto: programas e ações na unidade básica. 2. ed. São Paulo: Hucitec; 2000. p. 48-65.

15. Parker R, Camargo Jr. KR. Pobreza e HIV/AIDS: aspectos antropológicos e sociológicos. Cad Saude Publica. 2000;16(Sup1):89-102. DOI: 10.1590/S0102$311 \times 2000000700008$

16. Pereira JCR. Análise de dados quantitativos: estratégias metodológicas para as ciências da saúde, humanas e sociais. 3.ed. São Paulo: Edusp; 2001.p. 94-111.

17. Rudy ET, Mahoney-Anderson PJ, Loughlin AM, Metsch LR, Kerndt PR, Gaul Z, et al. Perceptions of Human Immunodeficiency Virus (HIV) testing services among HIV positive persons not in medical care. Sex Transm Dis. 2005,32(4):207-13.

18. Souza Jr PRB, Szwarcwald CL, Barbosa Júnior $A$, Carvalho MF, Castilho EA. Infecção pelo HIV durante a gestação: Estudo-Sentinela Parturiente, Brasil, 2002. Rev Saude Publica. 2004;38(6):764-72. DOI: 10.1590/ S0034-89102004000600003

19. Teixeira PR, Vitória MA, Barcarolo J. Antiretroviral treatment in resource-poor setting: the Brazilian experience. AIDS. 2004;18(Supl 3):5-7.

20. World Health Organization. The Joint United Nations Programme on HIV/AIDS. Guidance on providerinitiated HIV testing and counselling in health facilities. Geneva; 2007.

21. Valdisseri RO. HIV Counseling and testing: evolving role in HIV Prevention. AIDS Educ Prev. 1997;9(Supl 3):2-13.

22. World Bank. Implementation Completion Report Brazil: Aids and STD Control Project. Washington; 1998.

\footnotetext{
This research project was funded by the Ministry of Health's National STD and AIDS Program (276/2006).
} 